\section{FRI0114 DIAGNOSTIC VALUE OF NUCLEOSOME-SPECIFIC ANTIBODIES IN RECENT ACTIVE NON TREATED SLE}

if Goetz, ${ }^{2} \mathrm{RL}$ Humbel, ${ }^{3} \mathrm{JC}$ Monier, ${ }^{3} \mathrm{~J}$ Cohen, ${ }^{3} \mathrm{C}$ Andre, ${ }^{3} \mathrm{~A}$ Bacquey, ${ }^{3} \mathrm{~A}$ Chevailler, ${ }^{3} \mathrm{P}$ Chretien, ${ }^{3} \mathrm{~A}$ Escande, ${ }^{3} \mathrm{C}$ Johannet, ${ }^{3} \mathrm{~F}$ Oskmann, ${ }^{3} \mathrm{NO}$ Olsson, ${ }^{3} \mathrm{MF}$ Taillefer, ${ }^{4} \mathrm{~J}$ Sibilia. ${ }^{1}$ Immunopathology; ${ }^{2}$ Immunopathology, Hospital, Luxembourg, Luxembourg; ${ }^{3}$ Groupe d'Etude de l'Autoimmunité, Hospital, Strasbourg, France; ${ }^{4}$ Rheumatology

\subsection{6/annrheumdis-2001.149}

Background The nucleosome is considered as a major antigen in SLE and nucleosome-specific antibodies (Ab) seem to be the most specific and the earliest markers of SLE.

Objectives To evaluate different methods of detecting anti-nucleosome Abs and determine the diagnostic value of these Abs in recently active SLE.

Methods A 2 year (1998-99) prospective multicenter study in 13 European Immunopathology Centres (Groupe d'Etude de l'Auto-Immunite).

Patients: (i) 55 cases of recently active SLE (evolution $<1$ year), (ii) 50 other autoimmune diseases: 31 RA, 15 primary SJÖGREN'S syndrome, 2 scleroderma, 2 unclassified connective tissue disease.

IgG anti-nucleosome Abs were detected by ELISA or immunodot using different nucleosome preparations.

IgG anti-ds DNA Abs were detected by ELISA (calf thymus and human recombinant plasmid DNA).

Results

- 34/55 SLE patients had anti-nucleosome Abs reacting with 4 kits.

- 16/55 SLE patients had anti-nucleosome Abs reacting with 1 to 3 kits.

- 5/55 SLE patients were negative for anti-nucleosome Abs.

- 5/50 patients with other autoimmune diseases had antinucleosome Abs.

\begin{tabular}{|c|c|c|c|c|}
\hline & 1-ELISA (IgG) & $\begin{array}{l}\text { 2-ELISA } \\
(\operatorname{lgG})\end{array}$ & 3-ELISA (IgG) & $\begin{array}{l}\text { 4-Immunodot } \\
\text { (IgG) }\end{array}$ \\
\hline $\begin{array}{l}\text { Nuclear } \\
\text { extract }\end{array}$ & $\begin{array}{l}\text { Mouse } \\
\text { erythroleukemia cell } \\
\text { line }\end{array}$ & Calf thymus & Calf thymus & Calf thymus \\
\hline Antigen & Native nucleosomes & $\begin{array}{l}\text { Native } \\
\text { nucleosomes }\end{array}$ & $\begin{array}{l}\text { Nucleohistones } \\
\text { without H1 }\end{array}$ & $\begin{array}{l}\text { Nucleohistones } \\
\text { without H1 }\end{array}$ \\
\hline Sensitivity & 0.84 & 0.76 & 0.84 & 0.67 \\
\hline Specificity & 0.92 & 0.96 & 0.94 & 0.98 \\
\hline
\end{tabular}

Conclusion 50/55 (91\%) of patients with recently active SLE had anti-nucleosome Abs (by at least 1 method), 46/55 (84\%) also had anti-ds DNA Abs (by ELISA). The sensitivity and the specificity of the anti-nucleosome Abs for SLE depend on the method and the nucleosome preparation.

\section{FRI0115 SYSTEMIC LUPUS ERYTHEMATOSUS IN MEN}

${ }^{1} \mathrm{PV}$ Voulgari, ${ }^{1} \mathrm{P}$ Katsimbri, ${ }^{2} \mathrm{Y}$ Alamanos, ${ }^{1} \mathrm{AA}$ Drosos. 'Division of Rheumatology, Department of Internal Medicine; ' ${ }^{2}$ Department Hygiene and Epidemiology, Medical School, University of loannina, Ioannina, Greece

10.1136/annrheumdis-2001.150

Background
Objectives To evaluate whether gender influences the clinical course and outcome in systemic lupus erythematosus (SLE).

Methods Four hundred eighty-nine SLE patients were followed up at the University Hospital of Ioannina, Greece between 1981 and December 2000. These patients were reevaluated and the demographic, clinical, serological, radiological and therapeutic information were entered in a database. We divided our patients in two groups according to the gender. The disease activity and outcome were measured using the European Lupus Activity Score (ECLAM).

Results There were 421 women and 68 men, ratio 7:1. There were no differences between men and women concerning age, disease duration, age at disease onset and disease follow up. Except for serositis in men, which was significantly more frequent $(\mathrm{p}=0.01)$, organ involvement was not statistically different between the two groups. Laboratory evaluation showed that women had significantly higher levels of erythrocyte sedimentation rate compared to men ( $\mathrm{p}=0.001)$, while positive antinuclear antibodies and raised complement levels were more frequent in women $(p=0.08)$. There were no significant differences in ECLAM scores between the two groups as well as in the disease outcome for SLE patients.

Conclusion SLE in men is a rare disease and the clinical expression and disease outcome seem to be similar to those described in women.

\section{FRI0116 HYPERMOBILITY IN SISTEMIC LUPUS ERYTHEMATOSUS}

${ }^{1} \mathrm{M}$ Guma, ${ }^{1} \mathrm{~A}$ Olive, ${ }^{2} \mathrm{~J}$ Forcada, ${ }^{3} \mathrm{JC}$ Duró, ${ }^{4} \mathrm{~J}$ Roca, ${ }^{1} \mathrm{~S}$ Holgado, ${ }^{1} \mathrm{E}$ Casado, ${ }^{1} \mathrm{X}$ Tena. ${ }^{1}$ Rheumatology; ${ }^{2}$ Rheumatology, CAP St. Roc, Badalona; ${ }^{3}$ Rheumatology, Hospital Del Mar, Barcelona, Spain; ${ }^{4}$ Epidemiology, Hospital Del Mar

10.1136/annrheumdis-2001.151

\section{Background}

Objectives To investigate hypermobility in patients in systemic lupus erythematosus (SLE).

Methods Setting: University Hospital; 80 patients with SLE (1999 ACR criteria), 90\% females and 10\% males, mean age 44 \pm 16 , who regularly attended a specialist SLE clinic were examined. Control group was composed of 280 patients attending a general practitioner office, $70 \%$ females and 30\% males, mean age $46 \pm 19$. Joint laxity was measured according to Carter and Beighton criteria (total score 4 or more). A regression analysis was performed (SAS statistical package).

Results Forty-eight $\%$ or patients with SLE and 12\% of the control group were hypermobile. Regression analysis showed that after adjustment for the age and sex, patients with SLE were more hypermobile (Odds Ratio:5). Neither the clinical and analytical profile nor the use of corticosteroids was related to hipermobility.

Conclusion Patients with SLE are more hypermobile that control group. No clinical or analytical profile is related. Steroids are not related to the presence of hypermobility in patients with SLE.

\section{FRI0117 NEUROPSYCHIATRIC DISORDERS IN CHILDREN WITH SYSTEMIC LUPUS ERYTHEMATOSUS}

OV Shpitonkova, NS Podchernyaeva, TV Riabova. Pediatrics, Sechenov Moscow Medical Academy, Moscow, Russia

10.1136/annrheumdis-2001.152 